\title{
Recognition and Responsibility
}

\section{Hille Haker}

check for

updates

Citation: Haker, Hille. 2021. Recognition and Responsibility. Religions 12: 467. https://doi.org/ $10.3390 /$ rel12070467

Academic Editor: Dafydd Mills Daniel

Received: 4 May 2021

Accepted: 21 June 2021

Published: 25 June 2021

Publisher's Note: MDPI stays neutral with regard to jurisdictional claims in published maps and institutional affiliations.

Copyright: (C) 2021 by the author. Licensee MDPI, Basel, Switzerland. This article is an open access article distributed under the terms and conditions of the Creative Commons Attribution (CC BY) license (https:/ / creativecommons.org/licenses/by/ $4.0 /)$.
Department of Theology, Loyola University Chicago, Chicago, IL 60660, USA; hhaker@luc.edu

\begin{abstract}
While the concept of responsibility is a cornerstone of Christian ethics, recognition theory still lacks a thorough theological-ethical analysis. This essay seeks to fill the gap and develop normative ethics of recognition and responsibility. The first part provides a systematic analysis of the conceptual elements of recognition, emphasizing the need to focus on misrecognition as a heuristic tool and ethical priority. While recognition coincides with responsivity and attentiveness in the encounter of self and other, responsibility adds to this the moral accountability for acts, practices, structures, and institutions, rendering recognition and responsibility interrelated but also distinct principles of morality. This normative analysis is then correlated to the hermeneutical, narrative ethics of Christian ethics. The founding narrative of biblical ethics, the Cain and Abel narrative in Gen 4, is interpreted as a dialectic of recognition and responsibility. Both exegesis and ethics profit from this interdisciplinary and correlative approach between philosophical and biblical ethics. Finally, the ethics of recognition and responsibility, which emerges from the Frankfurt School critical theory, is confronted with exemplary indigenous approaches focusing on mutual responsibility as the foundation of ecological ethics. Christian ethics of recognition and responsibility resonates with this approach, yet emphasizes the distinctiveness of human interactions and the demands of moral responsibility.
\end{abstract}

Keywords: Christian ethics; critical theory; narrative ethics; recognition; responsibility; Honneth; Waldenfels; Levinas; Ricœur

\section{Introduction}

Over the last few decades, recognition has become an important concept in social and political philosophy, often associated with Charles Taylor's essay Multiculturalism and the Politics of Recognition (Taylor 1992, p. 237). Within the tradition of critical theory, however, Axel Honneth's study on Hegel, which was part a renewed interest in Hegel studies in Germany in the 1990s, is seen as the beginning of the recent reception history. The Struggle of Recognition was meant to complement the Frankfurt School's turn to discourse theory, represented by Jürgen Habermas and Karl-Otto Apel (Honneth 1995; Habermas 1984). Honneth criticized discourse ethics in its almost-exclusive turn to the communicative praxis of argumentation. It underestimates other practices, especially those that create cohesion and include the affective dimension of intersubjectivity. ${ }^{1}$ Retrieving Hegel's threefold structure of family, civil society, and state and adding insights from psychoanalysis concerning the constitution and development of self-identity, Honneth argued that recognition is grounded in the personal and social bonds among persons and groups, and these bring about the motivational energy to cooperate as equal partners and to transform unjust practices or structures. Honneth's approach is thus explicitly interested in the moral experiences of individuals who strive to interact and co-act with others whom they recognize and respect as moral agents. As a critical social theory, recognition theory seeks social transformations from within rationalized societies, the ever more "colonized lifeworlds" (Habermas) of late capitalism in which instrumental rationality determines more and more personal relations, social practices and institutions, and political decisions.

My approach to Christian ethics is situated in critical theory's social and political philosophy. ${ }^{2}$ I claim that the concept of recognition must be complemented by the concept of 
responsibility, and I will show that both are foundational to Christian ethics. Christian ethics is itself philosophical in its normative analyses of recognition and responsibility. However, its historical and experiential narratives of a transcendent God who is present in history, deepen the philosophical reflection. Narrative biblical ethics provides a hermeneutical lens to remember the particular histories of misrecognition and failures of responsibility, and it emphasizes that moral agents are entangled in the stories of their respective times and ages. I will show how narrative biblical ethics is correlative in its dual reflection on narrative and morality, and morality in narratives, constructive in view of biblical interpretations, and corrective in view of a traditional Catholic moral theology that often reductes ethics to normative judgments.

Human history, one could say, is a story of never-ending failures of recognition and responsibility, of human catastrophes told and recalled among others in the narratives of the bible and the history of the Church. When seen in retrospect, these catastrophes do pile up as Walter Benjamin pictured it in his interpretation of the image by Paul Klee, which Benjamin named the Angel of History. In his interpretation, the angel has turned his back to the future, looking at the past as a history of ever-growing catastrophes (Benjamin [1940] 2003; Mosès 2009). Christian witnessing and remembrance hold against this image of history the trust and hope that "another world is possible," to quote the motto of the World Social Forum. Yet, in order to "justify this hope" (1 Peter 3, 15), Christians must remember, first, the history of suffering and injustice and, second, the promise of peace and justice. The experience of misrecognition and failed responsibility in Christianity's own history, preserved in the biblical writings and testimonies throughout history, therefore paves the way to the normative claim of recognition and responsibility as the two central pillars of ethics in general, and Christian ethics in particular.

\section{The Discourse on Recognition}

\subsection{Dimensions of Recognition}

Recognition theories interpret the human desire to be seen and acknowledged by others, a condition that defines the dialectic of personal and social identity. Judith Butler summarizes the interdependency in terms of self-identity:

There is at some primary level a recognition that one's own life is bound up with this other life, and though this dependency changes form, I would suggest that this is the psychoanalytic basis for a theory of the social bond. ${ }^{3}$

I follow both Butler's and Honneth's emphasis on affective receptivity as the starting point of the deliberation on recognition. While Butler often emphasizes the paradox of subjectivation as subjection and individualization, Honneth emphasizes family relationships that bring about a sense of being and belonging. Ideally, the first "social bond" is woven from love, but it may also be the case that the family is the place of the first experience of misrecognition. ${ }^{4}$ The "given" family relationships are followed by "chosen" relations, e.g., in friendships and love relationships. Furthermore, there are other relations that are partly given and partly chosen, for instance, relations among co-workers in one's professional life, neighbors, or the members of the diverse networks in communities and organizations. As a local and global community, the Catholic Church at its best creates special bonds among its members that transcend any given affective bonds but that also surpass any boundary of culture, language, or history. It promotes solidarity with strangers who suffer and may be in need of solidaric actions.

For the purpose of this essay that is interested in the normative concept, I distinguish between four dimensions of recognition, namely the epistemological, the socialpsychological, the ethical, and the political. ${ }^{5}$

First, recognition entails an epistemological, "cognitive" element. In the English language, it is connotated in the "cognition" of re-cognition, and it is reflected in the French term reconaissance. In the German language, however, Anerkennung means first and foremost acknowledgment. This is linguistically distinct from Wiedererkennen, which is also 
connotated in the English recognition. ${ }^{6}$ Epistemologically, every act of recognition entails, at the same time, a non-cognition, because knowledge always comes with a blind spot (Bedorf 2010). Epistemologically, misreading, misunderstanding, or misrecognition are all part of the process of cognition and recognition, rendering the latter not a static judgment but a process and activity that is tightly linked to hermeneutics, the task of understanding and interpretation. The question then is how this epistemological limitation plays out in the ethical concept of recognition.

Second, recognition is a social-psychological condition of self-development: human beings must be socially recognized-affirmed, acknowledged, "adopted" and approached with positive affection and love in order to develop a positive self-identity. Clearly, infants are not subjects of their own making; they enter into preceding orders of meaning and understanding that they receive from their parents, caregivers, and environments in general. Individuals are certainly unique but at the same time, they are necessarily identified as particular subjects of a general class or category. Some identifications function as "identity maps" (gender and ethnicity especially), rendering the individuals recognizable (in the sense of recognition as Wiedererkennen) for others. However, these markers can easily become negative marks that are at the root of moral misrecognition (in the sense of denial of acknowledgment and respect as Anerkennung). Permanent degradation, stigmatization, and discrimination leave a mark in the psyche of an individual that inhibits self-confidence and trust in oneself and others, curtailing a person's flourishing and moral agency. ${ }^{7}$ In this respect, moral misrecognition goes far beyond epistemological or hermeneutical misrecognition.

Third, recognition reflects a normative concept underlying the expectations of a moral agent. This understanding is at the core of the Hegelian concept of moral identity and moral agency. Hegel's account of recognition corrects Kant's reductionist understanding of morality as autonomy, which Kant understood as the discernment of the self-given moral law. ${ }^{8}$ Instead, Hegel takes the possibility of mutual freedom in the encounter with the other as the central challenge to the possibility of morality-and in his later political writings, he tried to lay out how the French Revolution's principles of freedom, equality, and solidarity can be brought together in a political ethics. Personal relations as well as social bonds, which structure social interactions among agents, require norms in the form of laws that secure the rights of individuals and enable social freedom as solidarity. For Hegel, the experience of love provides the template for mutual recognition. It transcends an individual's egocentric pursuit of happiness by striving for the good of the other, while love secures one's own freedom or autonomy. Mutual recognition is therefore a normative ideal of nonviolent, caring, solidaric, and just inter-actions on the basis of freedom and equality (Hegel 2018). It goes far beyond the socially mediated self-constitution and instead offers a normative claim on personal and social relations as well as political institutions.

Fourth, recognition theory is sometimes reduced to the politics of recognition. In the United States, following Charles Taylor's book on recognition, it was received as a political theory of multiculturalism that is grounded in human dignity (Taylor 1992). Despite Taylor's motivation to establish a new understanding of tolerance, the reception of the political recognition theory has been critical, and it has also shaped the reception of Honneth's (different) theory of recognition. ${ }^{9}$ Prominently, Nancy Fraser warned early on that the politics of recognition may replace justice theories with identity politics, narrowing the ethical interest to cultural identity questions (Fraser and Honneth 2003). Her conversation with Honneth inspired several other studies, among them critics who point to the structural forms of misrecognition - as injustices-because of underlying biases and asymmetries of power. Indeed, as I have shown in my own works, too, conditional forms of recognition conceal an underlying moral, not merely epistemological misrecognition, for instance when seen through the lens of patriarchal or colonial norms that the to-be-recognized must adopt (Haker 1999, 2020b; Balaton-Chrimes and Stead 2017; Coulthard 2014). Both patriarchy and coloniality contain a conditional, power-affirming or power-sustaining concept of recognition: understood in this way, recognition is a judgment that "grants" someone 
status on terms set by only one party. Starting with an analysis of misrecognition is thus not only the better way to understand recognition-it is the only way to circumvent the ideological use of recognition.

From this complex reception history I want to take up the hermeneutical task of corrective interpretations, the damage that misrecognition does to the development of a self-identity, the isolating effect of exclusion and marginalization, the discrimination under conditions of inequality, and the overall impact of recognition (or misrecognition) on a person's moral standing in a society and polity. Misrecognition is more than misunderstanding; it entails a moral injury, inflicted upon someone in one single moment or over a stretch of time, in either case with lasting harm to the affected persons or groups. Misrecognition does not just happen. More often than not, it is intentionally used to humiliate another person. Misrecognition is not merely a judgment; it is an act, a practice, or a structure that is upheld by several social and political institutions. It involves a "doer" and a "done-to," and it is, therefore, to be subjected to moral critique. ${ }^{10}$ Misrecognition also implicates the bystander, the witness, the judge, the therapist, or the interpreter of experiences and structures that foster misrecognition. Positions matter for the ethical analysis, as do the intersecting obstacles to justice and equality that help identifying the different distributions of power and privileges or, vice versa, disenfranchisements, in different contexts (Crenshaw 2017). In the following, I will sharpen the ethical dimension of recognition, which will then pave the way to the interrelation of recognition and responsibility.

\subsection{Recognition Ethics}

Hegel's concept of recognition emerges from a conflict between two approaches to ethics, one centered on Kant's concept of deontological morality (Moralität) and the other centered on teleological ethical life (Sittlichkeit) that is often associated with Aristotle's ethics. For Kant, respect (Achtung) is formulated normatively in the categorical imperative, especially the so-called humanity clause that calls for the test of whether a maxim respects the humanity in one's own person as well as in every other person. In this reading, agents are necessarily moral agents, because they are bound to make choices that they need to justify. Because they are capable of reasoning, Kant holds that they ought to reflect upon their motives and decide whether these may count at the same time as justified reasons. Reasons of motivation and reasons of justification are distinct, and the former cannot take the place of the latter. The source of normativity in Kant's ethics is the freedom of the moral agent to give themselves the moral law. Even though no ultimate proof of freedom exists, it is a postulate that functions as a transcendental condition for any rational moral philosophy.

Hegel has a different interest. He explores the metamorphoses of self-consciousness, which are linked to history and the development of the self as a subject. Hegel's challenge, especially in the Phenomenology of the Spirit, is to preserve what Hobbes called natural freedom but develop it further, contra Hobbes, as social freedom. In other words: Hegel strives to spell out how individuals do not lose but find themselves in their interactions and encounters with others (Hegel [1833] 2011, 2018). Autonomy for Kant is self-legislation. For Hegel, it means personal, social, and political freedom for oneself and others in the encounters with others, in social relations that provide opportunities to cooperate, and in a polity that guarantees equal legal standing of its citizens. Being oneself is possible only in the mutual recognition of self and others in their free encounters, in social cooperation, and in just institutions.

Frankfurt School critical theory takes up this structure of freedom of the individual, equality of every human before the law, and solidarity among citizens. However, already the early Frankfurt School, Adorno and Marcuse in particular, departed from Hegel's claim to a new system philosophy. ${ }^{11}$ Following Marx's critical analyses of modern society under capitalism, the Frankfurt School unmasked the different kinds of distortions that exploit, oppress, and alienate people and peoples (Jaeggi 2014). The rise of Hitler's National Socialism with its open antisemitism that resulted in the Shoah forced most members of 
the Frankfurt School into exile. After the war, Adorno turned to Hegel's "metamorphoses" of the self, reversing his model of a progress history into a "negative dialectic." But Adorno still operates with a Kantian universalism, likewise turned into a negative one: "A new categorical imperative has been imposed by Hitler upon unfree mankind: to arrange their thoughts and actions so that Auschwitz will not repeat itself, so that nothing similar will happen" (Adorno [1966] 1983, p. 365).

My own approach maintains this skepticism about a progress history as well as the negative universalism. My interest, however, differs slightly from Honneth's initial focus: he takes acts, practices, and structures of misrecognition mostly as deviations from successful acts or practices of recognition. I am interested more in the two positions of moral agents, first as susceptible to the actions of others and, second, at risk of misrecognizing and disrespecting others through one's own actions. For Honneth, the concept of recognition has different functions in different contexts: for the constitution of self-identity, it is the condition. Read as Hegel's departure from the concept of liberty in Hobbes, recognition functions, second, as a normative principle of justice that constitutes the legitimacy of any political regime guaranteeing equality of all citizens in a given state. Third, for the social sphere and civil society, recognition is an ideal, aspirational as a concept of social freedom, yet rarely realized, as Honneth argues in his book on Freedom's Right, written twenty years after his initial study on Hegel (Honneth 2014). Ideologies "naturalize" social biases, transforming them into quasi-objective knowledge or truths that must not be questioned. In my view, however, they go far beyond what Honneth had earlier coined "pathologies" of a social body that must be subjected to an immanent critique (Honneth 2020). Rather, they must be unmasked as moral harms that affect people and groups so deeply that they cannot but struggle for change, even it means that they must risk their lives. The current Black Lives Matter movement is a good example of such a struggle. In part, it is indeed a struggle for recognition that entails the transformation of habits and attitudes, social practices, and/or institutions. However, it is also a fight for changes of concrete policies, among them policing and criminal justice. To judge this struggle in view of identity politics would be a bad mistake: it is a struggle for survival, and this is the reason why there is no alternative to the struggle to be seen and heard.

From an ethical perspective, we can now say that recognition ethics is not merely teleological or communitarian. Rather, it is an attempt to connect the normative/deontological and the evaluative/teleological dimension of morality, correlating legal rights with the personal bonds between individuals, and ideally with informal and formal practices of social cooperation among different groups of civil society. The critique of misrecognition provides a critique of moral harm, inflicted upon individuals and/or groups, in actions, practices, or structures. In the next part, I will therefore shift the perspective to the moral agents and their responsibility. I will begin this inquiry with some insights from phenomenology that allow me to link the affective side of recognition to the affective side of responsibility.

\section{Responsivity and Responsibility}

\subsection{Phenomenology of Responsivity}

German phenomenologist Bernhard Waldenfels explains the above-mentioned epistemological dimension of recognition via the concept of responsivity. Closely analyzing the encounter of self and other, Waldenfels argues that perception always begins with a "pathos" of experience (Widerfahrnis), followed by the response. ${ }^{12}$ Waldenfels emphasizes that humans are not only "birthed" out of pathos, ${ }^{13}$ they also create their world in perceptions by constantly giving the appearances a meaning. Most of the perceptions are learned and habituated, and they are therefore saturated with unreflected, quasi-naturalized meanings, including social judgments that are normally not questioned. Assimilation to the world that is filled with meanings that others have given to it defines the learning curve of self-development, including the development of moral agency. ${ }^{14}$ 
The pathos of experience is first and foremost disruptive, an occurrence that is suffered. This is already clear in basic perceptions: I am affected by something before I perceive it as something.

What provokes us, comes from a temporal and spatial distance towards us. It is always too early if measured in view of our self-initiative. On the other hand, our response is always too late measured in view of what occurs to us. It is not that something precedes us, for instance as causal stimulus with an effect that it brings about. We precede ourselves. [ ... ] I am younger and older than myself. We are dealing with an originary beforehandness and and a likewise originary belatednes. The consequence is that our speaking and acting is never entirely up to date. A response that begins elsewhere is separated from that to which it responds by a hiatus. For this time gap I choose the ancient expression diastasis. ${ }^{15}$

Identifying someone as someone cannot close the gap that sets up a dual alienness: between the self and the other, and between oneself and oneself. The deferment that defines the self as always coming too late, Waldenfels explains, "generates an irreducible sort of alienness which I call ecstatic alienness. I get outside myself, not by chance, illness or weakness, but by being who I am" (Waldenfels 2004, p. 242).

When something that appears in a person's horizon is someone who looks at me, I cannot help but seeing the gaze. "The gaze of the Other is nothing in my world but it is an event, in which a world opens and closes to me" (Waldenfels 2016). ${ }^{16}$ Yet, at the same time, the other is a double of the self, a Doppelgänger who is an "equal" to the self, even though "these equals remain unequal because of their singularity, which is rooted in their incarnate being, in their being here and now" (Waldenfels 2004, p. 245).

In the perception of the other, their gaze is not neutral: it is a smiling, threatening, asking, anxious gaze, etc. In contrast to the perception of things, landscapes, works of art, etc., the encounter with the other does not simply bring about an aesthetic play of interpretations. One cannot make oneself a spectator of the scene when the gaze is directed at oneself: I am the one who is looked at and thereby addressed: someone provokes me to be perceived, i.e., to be seen, heard, smelled, perhaps touched. ${ }^{17}$ The self is from the beginning a social self, distinct and connected to others in an entanglement that MerleauPonty and others have described as intercorporeity: "intercorporeity implies that the own and the alien are entangled, that everybody is inserted into an interlacing, into a Geflecht or entrelacs as Norbert Elias, Merleau-Ponty and sometimes even Husserl put it". (Waldenfels 2004, p. 246). Moreover, I want to add, the self is entangled in stories that they have not written but in which they are implicated. ${ }^{18}$

Waldenfels calls the prenormative sense of responsibility responsivity which he connects to attention (Aufmerksamkeit), response (Antwort), or attentiveness (Achtsamkeit), which in German has the same root as Kant's basic normative principle, respect or Achtung. Attending to someone who addresses, appeals, provokes, or summons the self means to re-spect (from the Latin word respicere), to look back—or, as Waldenfels says: to respond. In contrast to the ethics of autonomy, the phenomenology of responsivity reminds agents that their actions are secondary, re-actions rather than actions that the self initiates. Waldenfels emphasizes that the moments in which the self and the other reach an equilibrium do not erase the intrapsychic alienness or the alienness between oneself and others.

On the one hand, we can now sharpen the epistemological analysis of misrecognition with the help of phenomenology: misrecognition means to see someone either merely as alter ego, thereby erasing their uniqueness, or as entirely alien to oneself. ${ }^{19}$ On the other hand, recognition theory allows to clarify the ethical impact of perceptions, including the negative judgement of others: Othering is often an explicit rejection of the other. ${ }^{20} \mathrm{It}$ dehumanizes individuals and/or whole groups. For the person so exposed, the gaze may result in a self-perception in which the perspective of the other dominates or even defines the self. The self-identity may then be marked by shame and social stigma, as postcolonial and feminist writers have often emphasized. ${ }^{21}$ In the case of inflicted physical or emotional 
violence, the repression of one's own unique identity and the assimilation to the expected behaviors may be the only way to survive. ${ }^{22}$

The normative ethics of recognition and responsibility combines the necessity to be seen and acknowledged with the necessity to be responsive to each other in the self-other encounters. As a critical ethics, it closely attends to-and analyzes- the given and chosen relationships with an eye on experiences of misrecognition. Furthermore, it allows us to see the drama of misrecognition unfold in the social and political sphere.

Christian theology is often a translation, in the double meaning of translation from one language to the other and transfer of meanings from one place to the other. The three main classical languages of Christian theology all emphasize the gaze as an intimate and morally exceptional moment: in the Hebrew Bible, coming into the gaze of the other means to come face to face with them: panim-el-panim. When another person appears before someone, it means that someone appears to someone else as a person. Their gaze is a gaze toward someone: pro-sopon, the literal meaning of the Greek term "person". Further, in Latin, the other is present as persona, as a mask that shows the outer side of identity, but never the inner side of the self that is concealed from the gaze of others (Fanon [1952] 1967). "You cannot see my face, for no one may see me and live," God warns Moses (Ex 33:20). The ban on making an image of God is the first commandment that carries even more weight when seen through the lens of recognition: every image of God entails a misunderstanding or mis-recognition. ${ }^{23}$

Just like the self-other relation has generated the terms of entanglement and intercorporeity, ethics may speak of the entangled interactions and co-actions between or among agents as the appropriate starting point of any ethics. However, with Wilhelm Schapp, I want to insist that the entanglement also concerns diachronic relations: there is an entanglement with histories. Regarding its own history, Christian theology must, among others, reflect upon the intertwining of its own tradition with Judaism. Interestingly, it is in the Jewish biblical tradition that the foundational sources for practices and theories of attention, response, and respect can be found.

\subsection{The Demands of Responsibility}

Emmanuel Levinas and Paul Ricœur have been highly influential for late 20th-century ethical theory. When Levinas invokes recognition, he refers to the phenomenological tradition, reflecting the conditions of possibility of knowledge, which I distinguished from the Hegelian tradition of recognition as mutual acknowledgment. Like Waldenfels, too, Levinas is suspicious of recognition theory which he reads as reciprocal or quasi-contractual relationships that resemble Hobbes more than Hegel. Levinas never wrote about recognition in the sense of mutuality that I have developed above. ${ }^{24}$ Instead, he emphasizes responsibility as the core ethical concept. Moreover, it is pivotal for the constitution of the self as a moral agent. Moral agency transcends practical-ethical judgments. Contrary to any version of liberal or Kantian ethics of autonomy, the other's normative claim on the self is a pro-vocation to respond, if not a demand towards the agent to submit to the other. However, we need to be careful not to misread what Levinas means: moral agency in Levinas' terminology means to give oneself over, to surrender to the other-an ek-stasis that is the condition of becoming oneself as a self who is at the same time a moral self. In his hyperbolic expressions, Levinas emphasizes the sub-jection, for instance when he speaks of the self being taken hostage by the other, or bound by the obligation to respond. ${ }^{25}$ The infinite nature of the experience of the demand describes an experience of excess. In that sense, Levinas's ethics is deontic but not deontological, which would require that demands on others, even if not forced by coercion, are subjected to the test of justification. For Levinas, ethics is non-cognitive in the strict sense: it does not follow the cognitive assessment of a moral agent, as is the case in Kant's ethics or any deontological ethics. Levinas does not provide any criterion for the legitimacy of claims that bind an agent because he is not interested in this dimension of ethics: ethical reasoning, judgments, prudence, etc. do not capture the "core" of the moral claim in his view, which is the summons that pro-vokes 
a response. His ethics is indeed "otherwise than being," which at the same time means "beyond ethics" (Levinas 1998). Levinas does not consider that demands are mediated by social expectations and social norms, which often do not pass the test of justification and justice, and which are ethically problematic exactly for this reason. Furthermore, without attending to the concrete stories, the experience of the other as vulnerable, naked, violable being who is in need of another's attention, response, attentiveness, and respect (to recall the moral terms from the previous section), often remains as abstract as the normative precepts of the Deuteronomian Law.

Asymmetry rather than symmetry defines Levinas's ethics. It is, however, crucial to see that he begins with a premise, namely the power of the self over the other, because for Levinas, the self really has the capability to "kill" or "murder" the other. The encounter with the "naked face" of the other reverses this power dynamic morally while it continues to exist factually: only morality can lend power to the naked, vulnerable other, a paradoxical, moral power of the weak. Nakedness, this ethics says, ought to disarm the powerful. It is a power of pro-voking (appealing, claiming, demanding) not to kill but to care for the other-held against the self's potential impulse to kill, and sometimes even held against any ethical prudence. Yet, Levinas' thinking is difficult to fathom because his language echoes so much the "doer and the done to" syndrome that it can easily be confused with the heteronomy of the self towards the other (Benjamin 2017). This must make us uneasy, especially seen in light of the studies on the "authoritarian character" that the Frankfurt School provided. Norms that are grounded in authoritarian command structures, coercion, or violence contradict any notion of moral freedom, forcing the self to obey, pushing agents towards a particular action. That Levinas' ethics is not authoritarian in this sense can perhaps only be understood when its origin in the theological tradition is considered. The command of the "face" originates in the naked face of Abel who is to be cared for-or, in Waldenfels' parlor, attended to, responded to-by his brother Cain. Levinas speaks to the archetypical Cain, urging him to understand what is at stake, before any proclamation of the Fifth Commandment, the prohibition to kill. I will return to this foundational story below. Right now, however, I want to emphasize that, unlike a political law, the force of the moral command does not, Levinas holds, undo the self's freedom. ${ }^{26}$ Similar to Kant's categorical imperative, the answer to moral obligations is not blind obedience but self-binding. Unlike in Kant's autonomy or self-legislation, however, Levinas claims that it is the other, not the universal law, who binds the self. In his emphasis on unmediated normativity, Levinas ignores what critical theory warned about, namely that social norms are often the source of coercive, power-driven heteronomy. Furthermore, Levinas did not respond sufficiently to the critique that his hyperbolic language, against his intentions, echoes the language of domination when this is so often used to legitimize violent relationships, instead of reflecting the mutuality of recognition as normative demand. Certainly, the introduction of the Third and the demands of justice soften the absoluteness of the infinite demand that the other makes on the moral agent, creating some distance between the self and the other through the demand of equality. However, the problem is not merely a question of justice as equality and reciprocity: it is for the sake of mutual recognition that in one's moral agency judgments must have a place.

In contrast to Levinas, Paul Ricœur connects the concepts of recognition and responsibility. His anthropology of the capable human is indispensable for my own approach. I would even hold that I am taking up Ricœur's project where it remained unfinished due to his age.

\subsection{Responsibility and Recognition in Paul Ricour's Ethics}

Ricœur sees the roots of responsibility in the self's "aiming for a good life with and for others in just institutions" (Ricœur 1992, p. 172). The phrase captures the core of teleological ethics that Ricœur connects to a sense of justice. Ricœur does not stop here but goes on to argue with Kant for the necessity that the self subjects their aims (or maxims) to the test of justification. Ricœur thereby affirms the reciprocity of agents, formulated in the 
principles of autonomy and justice. ${ }^{27}$ Finally, Ricœur acknowledges that in practice, moral conflicts may emerge that must be resolved in recourse to prudential practical judgments. Some of these conflicts may turn out to be not resolvable morally because of the clash of several valid norms- these are tragic cases or moral dilemmas that ethical theory has always wrestled with. Moral agents may therefore not only be haunted by the infinity of their responsibility. They may also be haunted by a sense of tragic guilt in view of moral tragedies that cannot be reconciled. ${ }^{28}$ Other than Levinas, Ricœur demands, first, that moral agents judge their actions in view of respect for the dignity of other agents (Ricœur 2005, Part 2). However, similar to Adorno, he replaces Kant's formal categorical imperative with a single negative categorical imperative, namely to refrain from any maxim that may bring about that what ought not be, namely "evil". ${ }^{29}$ Second, also in contrast to Levinas, Ricœur elaborates on the relationship of recognition and responsibility in his last larger study, which he dedicated to this topic (Ricœur 2005). ${ }^{30}$ In his reading, mutual recognition must be contrasted to Hobbes' reading of reciprocity as the prudential choice of free agents. Rather, mutuality may be explained by recourse to the practice of gift-giving. While social theories often follow Marcel Mauss and associate gift-giving with practices in which a gift is given on the condition of being reciprocated with a return-gift, Ricœur now points to the unconditional gift-giving as an ethical demand. With this turn to the discourse on the gift, we can now see that a response is like the response-gift (not a return-gift) to the first gift of recognition that one must have received in order to become a self. In order to be more than prudential, the response to the other ought not to be a direct or indirect return gift. It ought not to be grounded in the imagination of how one would like to be treated oneself, as the Golden Rule has it-Ricœur rightly calls it a bridge to the moral principle, not the principle itself. A response can be considered ethical if it is given as if it were a first gift: not a pay-back, and with no demand of a return, it is a second-first gift, as Ricœur calls it (Ricœur 2005, Part 3, p. 243). Mutual recognition happens when self and other both demonstrate this attitude and engage in a generosity towards each other that is, paradoxically, not reciprocal but mutual. As an experience, so Ricœur's pessimistic verdict, mutual recognition is rather the exception than the rule. It is experienced in moments of peace in a world that is driven by prudential, instrumental reason, by conflict and misrecognition rather than by peace and recognition. In this, he echoes the pessimism of early critical theory, especially Walter Benjamin's and Adorno's (Benjamin [1940] 2003; Adorno [1966] 1983).

\section{Recognition and Responsibility}

So far, I have addressed the condition of recognition for the development of selfidentity, with particular interest given to the experiences of misrecognition. Furthermore, I have analyzed the concept of responsibility by way of the phenomenological tradition, grounding it in the perception theory of pathos and response. I have explained the normative dimension of recognition as mutual recognition of self and other in their free encounters and in just institutions, and I have identified the normative dimension of responsibility as the command to care for the other as well as a requirement to justify one's actions, the accountability for one's actions that originates in the capability to act.

With Ricœur's interpretation of the economy of the gift, the theological reading of God's first gift to the "earthlings," the blessing, affirmation, and adoption of humans by God gains a deep existential and ethical meaning. It not only explains the unconditionality of God's love that the Bible testifies to; it also explains that God's word is truly "in the beginning," the only word that is not already a re-action but the initiation of the entanglement between humans and God. The human response to God, in contrast, is a re-action. In this sense, it thus rests upon the experience of the pathos of recognition (as being recognized), which may be interpreted as God's unconditional acknowledgment of the goodness of creation, including humankind. The call for a response is expressed in ethical terms right from the beginning of human history, i.e., after the expulsion from the Garden of Eden. Certainly, the demand to attend to the other will be complemented with 
the respect to the other's uniqueness, and the accountability for indivduals' or collectives' actions. A new formulation of the moral principle, a modification of Ricœur's negative imperative, may therefore orient the quest for responsible responses: act in a way that your actions do not result in what ought not to be, namely the misrecognition (overpowering, shaming, humiliation, discrimination, or disrespect) of others. Yet, narrative biblical ethics will remind ethical theory that any normative claim is made on the basis of a prior acknowledgment: recognition precedes responsibility.

\subsection{Critical Ethics of Recognition and Responsibility}

Critical theory is not to be confused with criticism. First and foremost, critique is a method of discernment that analyzes social practices, attitudes and psychological structures as well as political institutions (Horkheimer 1972). Furthermore, it approaches the objects of study from an "engaged" perspective. Its partiality renders any neutrality or indifference towards suffering, moral harm, and injustice impossible. Critique does not mean that critical theory shies away from constructive discernments, as Habermas and Honneth have proven, and this combination of critique and engagement has made it an interesting method, too, for Christian theology (Metz 2007). My claim goes further than this general appropriation of critical theory in and for theology: I claim that critical theory is key to the understanding of misrecognition, while theology may deepen critical theory's own understanding of the dialectic of recognition and responsibility.

As Honneth has shown, the concept of mutual recognition enables ethics to uphold the normative ideal of freedom as a concept of intersubjectivity and on this basis to provide a critique of misrecognition. Elaborating further on what Ricœur began as a "course" in his lectures, I read Jessica Benjamin's work as a valuable contribution to the distinction of reciprocity and mutuality in recognition theory. Writing from a psychoanalytical perspective, Benjamin holds that mutual recognition happens exactly when agents attend to each other, act together and create something new (Benjamin 2017). Interestingly, Benjamin develops her approach in asymmetric relations in which the capability to act may be distributed unequally and recognition may then include the willingness to care for the other without expecting anything in return. For the asymmetric therapeutic constellation, Benjamin stresses that mutual recognition is necessary for the healing process exactly because it entails the practicing of mutuality and the survival of the failures of recognition. ${ }^{31}$ For instance, this process not only allows for the "attunement" between self and other; it also allows for both to set limits to the claims by the respective other and to insist on the difference between them. Depending on the constellation (including age or cognitive capacities etc.), it allows for agents to reflect and converse about failures of understanding, failures of recognition, and failures of acting together. Asymmetric relations may also include acts of standing in for the other, which is all the more necessary-Benjamin speaks of her therapeutic settings and here follows the works of Donald W. Winnicott-in cases of breakdowns or ongoing traumas. Following this understanding of mutuality as dynamic co-agency, the ethics of recognition certainly involve respect-but they go far beyond it: they provide a moral theory of intersubjectivity that spells out mutual recognition as a dynamic, risky, and creative process of moral interaction and acting together. Again, regarding recognition as the judgment of another person's worth from a non-engaged perspective of an uninvolved observer who is interested in the other as an object of interest but pretends to be unaffected by them is a misunderstanding. What is at stake in the ethical meaning of recognition is the unconditional affirmation of the other, creating the possibility of co-acting and intertwining interaction. Mutual recognition, especially seen as a dynamic and correctable process, must therefore not be confused with the ideology of misrecognition concealed as (paternalistic) recognition - and it must also not be confused with an uncritical approach to the other.

Recognition and responsibility belong together as concepts because they express a Gestalt shift in the doubling of the positions of self and other. The two concepts together point to the constant shifting of the positions of addressee and respondent, highlighting the different functions and roles within the agency concept. Because recognition is linked 
to the desire to be recognized, the experience of being seen, heard, and responded to does indeed stabilize the self-consciousness in self-other relations, social belonging, and legal status-just as misrecognition destabilizes the self's trust in the world (Bernstein 2015). The reflection on recognition is therefore closely related to the analyses of the vulnerability of individuals and groups to moral and structural harm. Responsibility focuses on the function of the responses and the role of the agent as a "respondent," including the accountability for their actions or omissions for which agents are praised or blamed. ${ }^{32}$ Interaction is dynamic: it includes verbal communication as the practice of understanding, meaning-making, and interpretation. Humans can indeed see each other as "of one kind" or as equals, as Waldenfels said. They can share certain goals and cooperate in pursuing them, for instance in friendships, collegiality, social movements, or political actions. These collective actions, alongside social experiences and historical memories, create as many bonds of belonging as unresolved conflicts can spark recurring hostility.

Like recognition, however, responsibility can be used ideologically. This is the case in policies that "privatize" responsibility way beyond the capabilities of individuals in highly differentiated societies, without providing them with the resources to respond to the challenges of their lives. ${ }^{33}$ The libertarian position especially has resulted in a culture of "responsibilization" that mostly deflects from the failures of political responsibility, but which also incorporates social biases regarding women, people who live in poverty, and ethnic minorities, with increasing vulnerability when these categories intersect. Under the responsibilization regime, women are overburdened with responsibilities to care for children or the elderly, while men are faced with the effects of patriarchal stereotypes of masculinity, demanding of them to be "in charge" in their private lives as well as in social and political institutions. Furthermore, gender-nonconforming people are not only excluded - they are rejected as inter-agents and participants in social affairs, even concerning their own lives. On another level, responsibililization means wrong socialization: for instance, civil society is asked to provide resources at times of crisis, but their acts of solidarity never result in systemic changes. Finally, the foundations of wealthy philanthropists who act without any democratic control create a quasi-political structure, undermining the core task of politics. ${ }^{34}$ The result is not only a permanent state of crisis for those who do not have the means or capacities to respond to demands they have to meet-financially as well as socially or professionally. ${ }^{35}$ They are held accountable for crises that have structural causes with collective actors, ${ }^{36}$ and they are blamed and shamed for making seemingly irresponsible choices as if they were not willing to take on the responsibility for their own lives. Calling for mutuality of recognition and responsibility in interactions certainly means to argue for freedom's right, as Honneth has called it. However, likewise, the vulnerability of agents must be accounted for, in its ontological, moral, and structural dimension. ${ }^{37}$ Recognition and responsibility must both be spelled out in personal relationships, social practices, and political institutions. Critical ethics of recognition and responsibility provides the tools for concrete, contextual analyses on all three levels.

\subsection{Recognition and Responsibility as a Hermeneutical Lens: Narrative Biblical Ethics}

In Genesis 4:1-16, the paradigmatic story of morality is told as part of the narrative of the origins of humans and the history of their faith. Cain misunderstands God from the beginning, mistaking his own sacrifices as a conditional gift to God for which he expects something in return. ${ }^{38}$ God refuses to act accordingly, although he does receive the sacrifice of Abel, the one whose identity is transient and ambiguous in the text. No matter how one interprets the constellation of the three actors in the story, God demands of Cain to care for his brother instead of being concerned about the reception of his sacrifice. Without a response to God's call (there are a lot of gaps that the reader must fill in), Cain becomes the first murderer in the Bible. The story depicts Cain's desire to be recognized by God, spelling out the tragic consequences of misunderstanding God's love and demands. Cain becomes as much the symbol of the desire for recognition as for the failure of responsibility. Being marked and put under God's protection in one symbol, Cain survives his moral failure, just 
as the people of God survive all following failures and mistakes despite all the catastrophes that pile up over the course of history. Theologically, they are countered by the stories of justice as a response to the harm done to others, and the ultimate hope in eschatological justice, the tikkun olam, or divine reconciliation in the kingdom of God that the Gospels take up in the new, diverse contexts of early Christianity. Human history entails the stories of the human condition in "case studies" of human experiences, including the paradox of being cursed and protected at the same time (LaCocque 2015, p. 32). Regarding Cain, his future is not all merely negative: he becomes the builder of the first city in the Bible. In the Christian tradition, the writers of the Gospels reaffirm the belief in the Kingdom of God, and God's blessings that form the center of (Jewish and) Christian ethics in the Sermon of the Mount. ${ }^{39}$ They also concur with Judaism that all ethical demands culminate in one, namely to love one's neighbor like oneself. The Gospel of John meditates on the intertwining of knowing (cognition) and loving (i.e., recognition), offering a particular interpretation of the relationship of God and his beloved Son. The gospels and the writings of the early church reflect upon particular experiences of particular people and groups, in particular locations, at a particular time. They convey these experiences and reflections in stories, letters, treaties, and poetry, a far cry from a homogeneous tradition to which scripture and tradition is sometimes reduced.

Recognition and responsibility are certainly not the only concepts that provide a hermeneutical lens to read the biblical stories ethically. However, they allow ethicists to reflect upon the narratives' depth and wisdom, and holding the narrative truths against the truths of discursive ethics. Rather than deriving normative claims directly from narratives, they serve as a medium of and for ethics. Because narratives are documents of meaningmaking, they are never neutral descriptions. Norms entail enveloped stories that must be unfolded, because they are the origin of the abstractions.

Reflecting upon its own tradition, theological ethics must be critical ethics. It offers critical analyses of social practices, correlates the hermeneutics of experiences and events with the normative demands of morality, and strives to provide constructive solutions to moral problems with the help of the tradition of practical reason. For this task, the complementary concepts of recognition and responsibility offer a philosophical and theological foundation, and I hold that they are both indispensable for the contextual analyses of ethical issues.

So far, I have said little about the politics of recognition and its critical reception. The critique concerns the "identity politics" that seems to be unavoidable. If that were the case, it would undermine rather than foster mutuality and justice. In addition to the critique from political theory, several scholars have stated their critique from a decolonial perspective, among them Native American scholar Glen Coulthard (Coulthard 2014). Instead of rehearsing this well-known critique, I want to address a constructive approach from within the indigenous traditions, albeit one that also includes a radical critique of Western self-understanding. This approach concerns the question of the relationship of humans to their non-human environment.

\subsection{Indigenous Ecology and the Ethics of Recognition and Responsibility}

Over the last few decades, numerous scientists, scholars, and groups have re-introduced the indigenous knowledge traditions to Western societies and the mainstream scientific community. ${ }^{40}$ Their work is aimed at a transformation of the destructive epistemological paradigm of domination, including the domination of nature, fellow human beings, and the earth. For the purpose of this essay, the concept of mutual responsibility is particularly interesting: Potowatomi scholar Robin Wall Kimmerer refers to mutual responsibility that emerges in everyday practices. In contrast to the discussion above, in the indigenous concept mutual responsibility goes beyond interactions among humans. Kimmerer points to the connection of gift-giving and gift-receiving with responsibility, now centered on ecology: 
The earth gives away for free the power of wind and sun and water, but instead, we break open the earth to take fossil fuels. Had we taken only that which is given to us, had we reciprocated the gift, we would not have to fear our own atmosphere today. We are all bound by a covenant of reciprocity: plant breath for animal breath, winter and summer, predator and prey, grass and fire, night and day, living and dying. Water knows this, clouds know this. Soil and rocks know they are dancing in a continuous giveaway of making, unmaking, and making again the earth. Our elders say that ceremony is the way we can remember to remember $[\ldots]$.

The moral covenant of reciprocity calls us to honor our responsibilities for all we have been given, for all that we have taken.

(Kimmerer 2013, p. 383f)

Kimmerer articulates this "give and take" in the traditional language of reciprocity. He does not take into account the difference between ecological reciprocity and mutuality that is so important in an ethical concept of recognition. Although he is sympathetic to Kimmerer's approach, Kyle Whyte, who also belongs to the Potawatomi tribe, goes a step further and speaks of mutual responsibility, aimed at overcoming the anthropocentric concepts. Whyte combines empirical ecological knowledge with the cultural and spiritual knowledge of interdependence and accountability: "For many Indigenous peoples, spirituality refers to moral relationships, especially accountability, that are tied to the pursuit of scientific knowledge (Whyte 2018; Warren and Karena 2002, p. 140f).

Interestingly, Pope Francis' signature encyclical also concerns ecology in terms of interdependency of all inhabitants of the earth (Pope Francis 2015). In his emphasis on an "integral ecology," Francis not only resonates with an ecocentric understanding of responsibility but also evokes the necessity of interdisciplinary ethics, which has been demanded for a long time by Catholic social ethicists (Holderegger and Wils 2001). The indigenous terminology of mutual responsibility takes up the language of the equilibrium, transcending the anthropocentrism of modern thinking in favor of a broader perspective that emphasizes the entanglement of non-human and human life. Critical ethics of recognition and responsibility can take up this ecological understanding of interdependency and interrelatedness. However, it adds the caveat that human responsibility presupposes moral agency, and only humans are to be held accountable for the incredible harm they have inflicted upon the planet.

Phenomenology, indigenous environmental ethics, and Christian ethics all coincide in their emphasis on perception as receiving. In the latter tradition, the narrative of creation in Genesis invokes a God who creates the world, blesses the earth's creatures, and leaves it to humans as its caretakers. JHWH knows humans even before they create them (Jer 1:5) and recognizes them in divine love: "I have loved you with an everlasting love; I have drawn you with unfailing kindness" (Jer. 31:3). The story of faith entails the history of recognition and misrecognition, responsibility and failure of responsibility. The story of the Covenant between God and Israel, and between God and all human beings entails the history of broken promises and unanswered love-not by God but by humans. Written and rewritten over the course of history, the biblical stories testify to the suffering, lamenting, and grieving God who in turn responds to the lament of the suffering people. In the continuum of the history of failures, stumbling, and stubbornness of the human, God is still willing to love, to forgive, and to renew the bond with the human. Stories preserve their own "alienness," the non-sayable in the said, the void within the story that is told, the un-nameable in the name of God (Levinas 1998). Theology must attend to its own narrative sources in ongoing acts of interpretation. In spite of the "unsayable" and "untellable," it turns to the concreteness of histories and stories because human beings are storytellers who must make sense and give meaning to what occurs to them. 


\section{Conclusions}

In conclusion, I want to emphasize some of the insights from the argument I made regarding the interrelation of recognition of responsibility and the merit to embrace the two concepts in Christian ethics:

First, in the current discourse, recognition is easily reduced to the positive judgment of the other's worth or status in relation to oneself or one's own culture. I have argued instead that the gap between the self and the other cannot be closed, requiring us to constantly interpret and reinterpret ourselves, the world we perceive, and others whom we encounter. Human experiences are mediated by the experiences and learned patterns of perception, identification, or drawing boundaries between oneself and others. The sediments of one's culture, history, and way of life are reflected in social norms that, among other things, define who is recognized, and who is not. Spelling out the ethics of critical theory, critical ethics analyzes in particular, acts and habits, practices, structures, and institutions of misrecognition, correlating these practices to a "negation of the negation," i.e., the possibility of mutual recognition in personal relationships, social interactions, and political institutions.

Second, like recognition, responsibility rests upon affective experiences, captured in the dual understanding of responsibility as responsivity and accountability. Although ethics cannot be reduced to norms and prescriptions, they are still part of practical reason that includes both argumentation and interpretation as its methods. Brought together, they allow for the discernment of one's commitments and life goals as well as for judgments of actions, practices, structures, and institutions. Critical ethics necessarily includes the questioning of laws that prescribe the scope of legitimacy in a given polity. The Christian tradition entails itself a history of moral reasoning with several different sources. Its methods, developments, authors, and reflection of human experiences cannot be captured in a singular philosophical tradition. Yet, as one approach within Christian ethics, the ethics of recognition and responsibility approaches moral practices and moral norms with an "interest" and commitment that aligns it with the struggles for recognition and justice, as they emerge at any given time.

Third, for decades, lay Catholic ethicists, in particular, were urged to submit to an ecclesial understanding of subordination and obedience that misrecognized academic as well as religious freedom. For many Catholics, the current task is to unlearn the patterns and the authoritarian habitus that has shaped the relationship between the officeholders and the members of the Church for centuries. Clerics who hold power in the Church have claimed that their power ought to be seen as service, even when it harms those over whom they hold power. They have claimed the superiority of the office and demand subordination and obedience of the people of God. Patterns of misrecognition come in many forms and practices, and there are many examples of the failures of responsibility, including the failure of the witnesses and bystanders, the interpreters and scholars of theological ethics. The task of Christian ethics is to name the moral injuries and harms, to listen to the stories of those who have been or are being harmed, to advocate for them when they are unable to speak for themselves or are not heard, and to provide an ethical critique without reducing ethics to criticism.

Fourth, complementing recognition with responsibility helps to understand that attentiveness to the other is a habitus that must be developed, learned, and practiced in the humility that what one has received always exceeds that what one can give. Practices of recognition and responsibility aim to overcome moral and structural violence. Their underlying ethical theory claims that prudential, contractual relationships, even though they are reciprocal, are not the same as mutual recognition. There are indeed boundaries of what others can demand of the self. Moral boundaries, however, are constantly negotiated and renegotiated, and agents do have obligations for which they must be held accountable. Repentance, forgiveness, and reconciliation are practices that have a strong foothold in the Christian tradition. They, too, are responses that are meant to repair misrecognition. 
Mutual recognition and mutual responsibility exist because humans are vulnerable to being harmed as well as capable of responding to others and account for their actions. Christians, well aware of Christianity's own ongoing history of failing to meet the demands of recognition and responsibility, acknowledge the finitude and fallibility of humans. However, it also remembers that humans are endowed with the creative freedom of bringing about change. Critical ethics may therefore foster not only a sense of humility regarding one's own and others' failures of recognition and responsibility but also the self-confidence of morally responsible, vulnerable agents.

Funding: This research received no external funding.

Conflicts of Interest: The author declares no conflict of interest.

\section{Notes}

For the link between morality and discourse theory see (Habermas [1983] 1990).

For the contextualization and argumentation see (Haker 2020a).

See (Butler 2020, kindle edition position 1138). Butler's work on recognition and responsibility, deeply influenced by the Frankfurt School and developed in conversation with it. Whereas Honneth works with Winnicott and Jessica Benjamin's psychoanalyis, Butler is more influenced by French psychoanalysis, Lacan in particular. Her approach to recognition theory can be seen as the counterpart to Taylor's politics of recognition. My own work takes her interest in both recognition and responsibility serious, but in this essay, I develop them into a singluar ethical approach, the ethics of recognition and responsibility. For my analysis of Butler's concept of the moral self see (Haker 2005).

4 I borrow the terms from psychoanalist's Jessica Benjamin's book on parent-child and more specifically, mother-child relationships (Benjamin 1988). See also the instructive study on personal relationships (Benjamin 2013).

5 For a reconstruction of the history of the idea of recognition in France, Britain, and Germany, see Axel Honneth's study, first published in German in 2018. This book is also a response to the different versions of recognition that have emerged over the last decades. Honneth's systematic account differs, however, in important points from mine, especially concerning the ethical dimension of the concept to which I turn below (Honneth 2020).

6 For the problems with the linguistic differences of the term see (Ricœur 2005). Because the term recognition is commonly used as translation of Anerkennung, however, I will stick to it, too.

7 See for a thorough study on the effects of misrecognition (Bernstein 2015).

8 For my purpose in this paper, I will not debate whether Hegel (deliberately) misinterpreted Kant; however, it is clear that he was influenced by Schiller's critique of Kant's ethics, raised from an aesthetic perspective that points to the relevance of moral emotions (Schiller 1971, 2016; Herdt 2020).

$9 \quad$ Patchen Markell is especially influenced by Arendt but overlooks the much more complex conceptualization, especially when one goes beyond Honneth or Taylor (Markell 2003). Especially harsh is (McNay 2008). Rarely did the critics mention the particular context within the Frankfurt School's own debates, or engaged in thorough readings of Hegel's theory of recognition. See, however (Pippin 2000; Williams 2012, 1997).

10 I borrow the term "doer and done to" from Jessica Benjamin (Benjamin 2017).

11 Critical theory countered Hegel's optimism with the warning of the "dialectic of englightenment", i.e., the violence underneath the surface of the seemingly peaceful "civilization" (Adorno and Horkheimer [1944] 2016; Adorno [1966] 1983).

12 "Widerfahrnis or af-fect, marked by a hyphen in order to suggest that something is done to us." "I have suggested using the term patient in its literal sense in order to underline this passive pre-status of the so-called subject. The corresponding status would be that of a respondent who re-spond to what strikes him or her" (Waldenfels 2004, p. 238). For a short introduction into Waldenfels' work see (Waldenfels 2011).

13 Waldenfels (2004, p. 242). For a similar account see (Butler 2005).

14 Waldenfels' analyses match with Judith Butler's reflections on phenomenology and subjectivity in (Butler 2015).

15 "Was uns anspricht, dringt aus einer zeiträumlichen Ferne zu uns. Es kommt immer schon zu früh, gemessen an unserer Eigeninitiative. Umgekehrt kommt unsere Antwort zu spät, gemessen an dem, was uns widerfährt. Es ist nicht so, dass etwas uns vorausgeht, etwa als kausaler Stimulus, der eine Wirkung nach sich zieht. Wir gehen uns selbst voraus. [ ... ] Ich bin jünger und älter als ich selbst. Wir haben es mit einer originären Vorgängigkeit und einer ebenso originären Nachträglichkeit zu tun. Dies hat zur Folge, dass unser Reden und Tun nie völlig auf der Höhe der Zeit ist. Ein Antworten, das anderswo beginnt, ist von dem, worauf es antwortet, durch einen Hiatus getrennt. Für diese Zeitverschiebung wähle ich den alten Ausdruck Diastase." (Waldenfels 2010, p. 77f), (my translation, emphasis in the text).

16 "Der Blick des Anderen ist nicht etwas in meiner Welt, sondern er ist ein Geschehen, in dem eine Welt sich mir öffnet und verschließt". (Waldenfels 2016, p. 384) (my translation). 
The "gaze" also concerns the crossing of boundaries between animals and human, among others (Derrida 2002) Aesthetic experiences depend upon the response by a reader to an address, for example by a poem (Haker 2020a, chp. 12: Responsibility for the Past). Husserl student (Schapp 1953; Haker 1999). For the concept of responsibility by implication (Rothberg 2019). For a thorough study of the 'other' see (Theunissen 1984) Today, one would want to add to this group Emmanuel Levinas.

Waldenfels is, of course, aware of the effect of othering and has dedicated several works to it, but he shies away from a normative ethical theory. See (Waldenfels 2006). For an analysis of the othering of black people in American literature (Morrison 2007, 2017). The seminal study in feminist theology by (Plaskow 1980) An important existentialist argument was provided by Simone de Beauvoir (De Beauvoir 1962). For the postcolonial context see (Fanon [1952] 1967).

Philip Roth has told the drama of identity in many of his novels. One striking example is The Human Stain, in which the protagonist conceals for decades the secret of his ethnicity in order to pursue a career that he would have otherwise been denied (Roth 2000).

Adorno creates an interesting link between theology and critical theory, using the notion of the Bilderverbot or image ban: "The materialist longing to grasp the thing aims at the opposite [of idealism]: it is only in the absence of images that the full object could be conceived. Such absence concurs with the theological ban on images. Materialism brought that ban into secular form by not permitting Utopia to be positively pictured; this is the substance of its negativity. At its most materialistic, materialism comes to agree with theology. Its great desire would be the resurrection of the flesh, a desire utterly foreign to idealism, the realm of the absolute spirit" (Adorno [1966] 1983, p. 207). For a discussion of the image ban in Adorno's work (Pritchard 2002).

See for a (in my view misleading) identification of recognition and responsibility in Levinas' works (Sohn 2014). For the linguistic distinctions of the French terms (Ricœur 2005, Part 1).

For a more thorough analysis see (Haker 2005).

See (Levinas 1990) There is a long discussion surrounding the Law and Violence that wrestles with an essay by Walter Benjamin (Benjamin 1996). Inspired by Levinas, Jacques Derrida took this discussion further and used it as a critique of justice in the name of responsibility (Derrida 1992, 1999).

In Oneself as Another, Ricœur still follows John Rawls but he returns to the question of justice in later works that take another turn inspired by the political philosophy of Hannah Arendt, which is not the subject of my essay. (Haker 2020a, chp. 1, No Place Nowhere. Refugees and the Problem of Human Dignity and Rights in Arendt and Ricœur).

The justification of lying to persecutors in order to save the life of a friend is a textbook example for such a dilemma, invoked already by Kant who unconvincingly argues that even in this extreme situation, truthfulness must trump the impulse to lie. Ricœur discusses the difficult case of abortion as a tragic dilemma. Sociological and ethnograpical studies support this claim: abortions often result in a sense of tragic guilt even when women continue to believe they made the right decision. This also supports the claim that no matter what position one takes, abortion must be discussed as a moral problem (Boltanski 2007; Haker 2011).

Ricœur (1992, p. 218). Critical theory insists that "evil" may easily be detached from the concreteness of violence and atrocities. It therefore the names, narrates, and analyzes historical experiences in empirical studies.

Ricœur (2005, Part 2). It deals with the "capable human" who can be held accountable for their actions and thereby connects recognition and responsibility.

31 Her argumentation has drawn some critique, in my view in a misreading of her understanding of mutuality. See among others (Orange 2010).

A good study on the scope of responsibility from an analytical perspective is (Mason 2019).

See for a critical assessment of the politics of responsibility (Lavin 2008).

The man-made crisis of days of power outage in Texas in early spring of 2021 after a few days of unusual winter storms is just one example of how the failure of responsibility results in moral harm (Ball 2021).

The multiple facets of poverty in the United States are, for instance analyzed in (Haymes et al. 2014).

See (Young 2011).

I elaborate on the concept of vulnerable agency in (Haker 2020a, chp. 5, Vulnerable Agency. Human Dignity and Gendered Violence).

Perhaps the names Cain and Abel already point to what is at stake in the story, namely the envy between the two brothers. Karolien Vermeulen interprets the name of Cain, the "acquired," as associated with being the property of someone else but she remarks that some associate it with jealosy. Abel's name stands for breath, vapor, and transience. In any case, the story entails the perspective of only one of the brothers who clearly struggles to be recognized by God while Abel, evoking transience and breath in his name, has no voice in the story. The story itself thus creates an interpretative gap, a narrative ambiguity that provokes the reader to fill in what is missing. The readers thereby continue the conversation that the story begins but certainly does not complete (Vermeulen 2014). For the context, interpretation and relevance of the Sermon of the Mount see (Hagner 1997).

\section{References}

Adorno, Theodor Wiesengrund. 1983. Negative Dialectics. New York: Continuum. First published 1966.

Adorno, Theodor, and Max Horkheimer. 2016. Dialectic of Enlightenment. London: Verso Books. First published 1944. 
Balaton-Chrimes, Samantha, and Victoria Stead. 2017. Recognition, Power and Coloniality. Postcolonial Studies 20: 1-17. [CrossRef] Ball, Jeffrey. 2021. The Texas Blackout Is a Story of a Disaster Foretold. Texas Monthly, February 19.

Bedorf, Thomas. 2010. Verkennende Anerkennung. Berlin: Suhrkamp.

Benjamin, Walter. 2003. On the Concept of History. In Walter Benjamin: Selected Writings, Vol. IV, 1938-1940. Edited by Howard Eiland and Michael W. Jennings. Cambridge: Harvard University Press, pp. 389-400. First published 1940.

Benjamin, Jessica. 1988. The Bonds of Love: Psychoanalysis, Feminism, and the Problem of Domination. New York: Pantheon Books.

Benjamin, Walter. 1996. Critique of Violence. In Walter Benjamin: Selected Writings, Vol. I, 1913-1926. Edited by Marcus Bullock and Michael W. Jennings. Cambridge: Harvard University Press, pp. 236-52.

Benjamin, Jessica. 2013. The Bonds of Love: Looking Backward. Studies in Gender and Sexuality 14: 1-15. [CrossRef]

Benjamin, Jessica. 2017. Beyond Doer and Done To: Recognition Theory, Intersubjectivity and the Third. New York: Routledge.

Bernstein, Jay. 2015. Torture and Dignity: An Essay on Moral Injury. Chicago and London: The University of Chicago Press.

Boltanski, Luc. 2007. Soziologie der Abtreibung (La Condition Foetale: Une Sociologie De L'avortement Et De L'engendrement, Paris 2004). Frankfurt: Suhrkamp.

Butler, Judith. 2005. Giving an Account of Oneself. Oxford: Oxford University Press.

Butler, Judith. 2015. Senses of the Subject. New York: Fordham.

Butler, Judith. 2020. The Force of Nonviolence: An Ethico-Political Bind, Kindle edition. London: Verso.

Coulthard, Glen Sean. 2014. Red Skin, White Masks: Rejecting the Colonial Politics of Recognition. Minneapolis: University of Minnesota Press.

Crenshaw, Kimberlé W. 2017. On Intersectionality: Essential Writings. New York: The New Press.

De Beauvoir, Simone. 1962. The Ethics of Ambiguity. New York: Citadel Press.

Derrida, Jacques. 1992. Force of Law. The "Mystical Foundations of Authority". In Deconstruction and the Possibility of Justice. Edited by Drucilla Cornell, Michael Rosenfeld and David Gray Carlson. New York: Routledge, pp. 3-67.

Derrida, Jacques. 1999. Adieu to Emmanuel Levinas. Stanford: Stanford University Press.

Derrida, Jacques. 2002. The Animal That Therefore I Am (More to Follow). Critical Inquiry 28: 369-418. [CrossRef]

Fanon, Frantz. 1967. Black Skin. White Masks. New York: Grove Press. First published 1952.

Fraser, Nancy, and Axel Honneth. 2003. Redistribution or Recognition? A Political-Philosophical Exchange. London and New York: Verso. Habermas, Jürgen. 1990. Moral Consciousness and Communicative Action. Cambridge: MIT Press. First published 1983.

Habermas, Jürgen. 1984. The Theory of Communicative Action. London: Heinemann.

Hagner, Donald Alfred. 1997. Ethics and the Sermon on the Mount. Studia theologica 51: 44-59. [CrossRef]

Haker, Hille. 1999. Moralische Identität. Literarische Lebensgeschichten Als Medium Ethischer Reflexion. Mit Einer Interpretation Der "Jahrestage" Von Uwe Johnson. Tübingen: Francke.

Haker, Hille. 2005. The Fragility of the Moral Self. Harvard Theological Review 97: 359-82. [CrossRef]

Haker, Hille. 2011. Hauptsache Gesund? Ethische Fragen der Pränatal und Präimplantationsdiagnostik. München: Kösel.

Haker, Hille. 2020a. Towards a Critical Political Ethics. Catholic Ethics and Social Challenges. Studien Zur Theologischen Ethik 156. Basel: Schwabe Verlag.

Haker, Hille. 2020b. Towards a Decolonial Narrative Ethics. In Ethics and Literary Practice. Edited by Adam Zachary Newton. Basel: MDPI, pp. 72-102.

Haymes, Stephen, Maria Vidal De Haymes, and Miller Reuben. 2014. The Routledge Handbook of Poverty in the United States. Abingdon: Taylor \& Francis.

Hegel, Georg Wilhelm Friedrich. 2011. Natural Law. Philadelphia: University of Pennsylvania Press. First published 1833.

Hegel, Georg Wilhelm Friedrich. 2018. Georg Wilhelm Friedrich Hegel: The Phenomenology of Spirit. Translated by Terry Pinkard. Cambridge: Cambridge University Press.

Herdt, Jennifer. 2020. Forming Humanity: Redeeming the German Bildung Tradition. Chicago Scholarship Online. Chicago: The University of Chicago Press.

Holderegger, Adrian, and Jean-Pierre Wils. 2001. Interdisziplinäre Ethik: Grundlagen, Methoden, Bereiche: Festgabe für Dietmar Mieth zum sechzigsten Geburtstag. Fribourg: Schwabe Verlag.

Honneth, Axel. 1995. The Struggle for Recognition: The Moral Grammar of Social Conflicts. Cambridge and Oxford: Polity Press, Cambridge: Blackwell.

Honneth, Axel. 2014. Freedom's Right. The Social Foundations of Democratic Life. New York: Columbia University Press.

Honneth, Axel. 2020. Recognition. A Chapter in the History of European Ideas. Cambridge: Cambridge University Press.

Horkheimer, Max. 1972. Traditional and Critical Theory. In Critical Theory: Selected Essays. Edited by Max Horkheimer. New York: Continuum.

Jaeggi, Rahel. 2014. Alienation. New York: Columbia University Press.

Kimmerer, Robin Wall. 2013. Braiding Sweetgrass: Indigenous Wisdom, Scientific Knowledge and the Teachings of Plants, 1st ed. Minneapolis: Milkweed Editions.

LaCocque, Andre. 2015. Onslaught against Innocence: Cain, Abel and the Yahwist. Cambridge: James Clarke \& Co.

Lavin, Chad. 2008. The Politics of Responsibility. Urbana: University of Illinois Press.

Levinas, Emmanuel. 1990. Difficult Freedom: Essays on Judaism. London: Athlone Press.

Levinas, Emmanuel. 1998. Otherwise Than Being, or, Beyond Essence. Pittsburgh: Duquesne University Press. 
Markell, Patchen. 2003. Bound by Recognition. Princeton: Princeton University Press.

Mason, Elinor. 2019. Ways to Be Blameworthy: Rightness, Wrongness, and Responsibility. Oxford: Oxford University Press.

McGregor, Deborah, Steven Whitaker, and Sritharan Mahisha. 2020. Indigenous Environmental Justice and Sustainability. Current Opinion in Environmental Sustainability 43: 35-40. [CrossRef]

McNay, Lois. 2008. Against Recognition. Cambridge: Polity Press.

Metz, Johann Baptist. 2007. Faith in History and Society (Glaube in Geschichte und Gesellschaft, 1977). New York: Crossroad.

Morrison, Toni. 2007. Playing in the Dark. New York: Knopf Doubleday Publishing Group.

Morrison, Toni. 2017. The Origin of Others. Cambridge: Harvard University Press.

Mosès, Stephane. 2009. The Angel of History: Rosenzweig, Benjamin, Scholem. Stanford: Stanford University Press.

Orange, Donna M. 2010. Recognition as Intersubjective Vulnerability in the Psychoanalytic Dialogue. International Journal of Psychoanalytic Self Psychology 5: 227-43. [CrossRef]

Pippin, Robert B. 2000. What Is the Question for Which Hegel's Theory of Recognition Is the Answer? European Journal of Philosophy 8: 155-72. [CrossRef]

Plaskow, Judith. 1980. Sex, Sin, and Grace: Women's Experience and the Theologies of Reinhold Niebuhr and Paul Tillich. Lanham: University Press of America.

Pope Francis. 2015. Encyclical Letter "Laudato Si" on the Care for Our Common Home. Vatican: Vatican Press.

Pritchard, Elizabeth A. 2002. Bilderverbot Meets Body in Theodor W. Adorno's Inverse Theology. The Harvard Theological Review 95: 291-318. [CrossRef]

Ricœur, Paul. 1992. Oneself as Another. Chicago: University of Chicago Press.

Ricœur, Paul. 2005. The Course of Recognition. Cambridge: Harvard University Press.

Roth, Philip. 2000. The Human Stain: A Novel. Boston and New York: HMH Books.

Rothberg, Michael. 2019. The Implicated Subject: Beyond Victims and Perpetrators. Cultural Memory in the Present. Stanford: Stanford University Press.

Schapp, Wilhelm. 1953. In Geschichten verstrickt. Vom Sein von Mensch und Ding. Hamburg: Meiner.

Schiller, Friedrich. 1971. Kallias, Oder über die Schönheit. Über Anmut und Würde. Stuttgart: Reclam.

Schiller, Friedrich. 2016. On the Aesthetic Education of Man. London: Penguin.

Sohn, Michael. 2014. The Good of Recognition: Phenomenology, Ethics, and Religion in the Thought of Levinas and Ricœur. Waco: Baylor University Press.

Taylor, Charles. 1992. Multiculturalism and the Politics of Recognition: An Essay. Edited by Amy Gutmann. Princeton: Princeton University Press.

Theunissen, Michael. 1984. The Other. Studies in the Social Ontology of Husserl, Heidegger, Sartre, and Buber (Orig.: Der Andere: Studien zur Sozialontologie der Gegenwart, 1977). Cambridge: MIT Press.

Vermeulen, Karolien. 2014. Mind the Gap: Ambiguity in the Story of Cain and Abel. Journal of Biblical Literature 133: $29-42$.

Waldenfels, Bernhard. 2004. Bodily Experience between Selfhood and Otherness. Phenomenology and the Cognitive Sciences 3: 235-48. [CrossRef]

Waldenfels, Bernhard. 2006. Schattenrisse der Moral. Frankfurt am Main: Suhrkamp.

Waldenfels, Bernhard. 2010. Responsive Ethik zwischen Antwort und Verantwortung. Deutsche Zeitschrift für Philosophie 58: 71-81. [CrossRef]

Waldenfels, Bernhard. 2011. Phenomenology of the Alien: Basic Concepts. Studies in Phenomenology and Existential Philosophy. Evanston: Northwestern University Press.

Waldenfels, Bernhard. 2016. Das Leibliche Selbst. Vorlesungen zur Phänomenologie des Leibes. Frankfurt am Main: Suhrkamp.

Warren, Magnusson, and Shaw Karena. 2002. Political Space: Reading the Global through Clayoquot Sound. Globalization and Community. Minneapolis: University of Minnesota Press.

Whyte, Kyle. 2018. Critical Investigations of Resilience: A Brief Introduction to Indigenous Environmental Studies and Sciences. Daedalus 147: 136-47. [CrossRef]

Williams, Robert R. 1997. Hegel's Ethics of Recognition. Berkeley: University of California Press.

Williams, Robert R. 2012. Tragedy, Recognition, and the Death of God: Studies in Hegel and Nietzsche. Oxford: Oxford University Press.

Young, Iris Marion. 2011. Responsibility for Justice. Oxford and New York: Oxford University Press. 